\title{
Hate Speech in Cyber Society of Brazil: Portraits of the Elections in 2014 by Critical Analysis of Norman Fairclough
}

\author{
Silvia Regina Pochmann de Quevedo \\ Journalist -Engineering and Knowledge Management, $\mathrm{PhD}$
}

\begin{abstract}
This study aimed to investigate the discursive practices and beliefs produced in the Brazilian presidential elections by hate speech from the perspective of Critical Discourse Analysis (CDA) proposed by Norman Fairclough (2001), which includes speech and interprets its effects from the contextualization social problem. The study includes the semiotic process involving multiple languages and structural analysis. The research focused on the cybersociety portrayed by Facebook, the social network more accessible in Brazil. In October 2014 Brazil experienced a fierce campaign for the presidency in 30 years, since the end of military dictatorship and the first with a great impact on social networks. This campaign, which had Facebook as massive platform of public debate, gave rise to a hate speech and fielded two armies that battled in the virtual world. This article demonstrates the emerging hatred found in Brazilian cybersociety for the first time in the most intense period, the second round of the election campaign. The study aimed to investigate how each candidate was represented discursively over that period, what kinds of beliefs were produced and, consequently, that representation of reality social network offered. From the identification of a social problem - the reason was the emergence of hate - the social and discursive analysis proposed by Fairclough, under the sign of the numerous semiosis web language, punctuate the social barriers and social interests not solve it does, and identify the possibilities of overcoming these same obstacles. The method involved systematic review of literature with the interdisciplinary databases and participant observation in the social network, with collection of 281 screens through print screen. The screens were organized in spreadsheet from the concepts: Aécio Neves, Dilma Rousseff, Lula, FHC, PT, PSDB, Voters Pro-Aécio, Voters Pro-Dilma, robots and media. The concepts were crossed with the following categories: different stages of impact of hate, tolerance and convergence, which resulted in modalities under which the screens were indexed via hyperlinks. The discursive analysis Fairclough revealed that the Brazilian, seen as peaceful and friendly, was able to achieve the greatest degree of hatred that period hatred that incites violence. The candidate Dilma Rousseff (Workers Party) received the highest number of attacks this level, being associated by opponents voters a sense of demonization and terror, and portrayed as drunk, incompetent, stupid, ugly, liar, among other adjectives. The candidate Aécio Neves (Brazilian Social Democracy Party) is represented, in the view of opponents voters as cocaine user, drunk, liar and wife beater. The study showed a behavior speculate among netizens, here called mirroring, when both armies copied strategies from convergence marks. The discursive reality presented together with its social implications demonstrates that investments in education need to be expanded so massive and that the break with the current economic model can represent a large and profitable social progress for the country.
\end{abstract}

Keywords: Brazilian cybersociety; hate speech; election presidential

\section{Introduction}

In October 2014 two armies in Brazil were face to face fighting over the nation's political power, the best style of street battles. The confrontation between these armies, however, occurred in the virtual world. The explosion of Internet access by mobile devices and the consolidation of the Facebook platform as massive public debate brought new challenges to election campaigns (SILVEIRA, 2014, p.11).

The dispute on Facebook, so the social network more accessible to Brazilians brought up different voices on a large scale and simultaneously, framed by an emerging hate speech. Ahead of these armies were Dilma Rousseff (PT/Workers Party) and Aécio Neves (PSDB/ Brazilian Social Democracy Party), elected for a second round that lasted 21 days of confrontation.

With a difference of 3.4 million votes, the result which gave victory to Dilma reflected the fierce electoral battle since the end of military dictatorship and the beginning of democratization of the country, in the 1980s. In cybersociety, the speech was potentiated the intensive semiotization process of language that the web provides, reflecting the beliefs of internet voters. Your beliefs exposes the reality that is created discursively in invested ideology texts, which, in turn, reflect the power struggles (MEURER, 2005). The speeches are related to structural analysis (produced beliefs and knowledge), and social and discursive practices interconnected with the social context as places Critical Discourse Analysis (CDA) proposed by British linguist Norman Fairclough. 
In Fairclough (2001), all production of meaning is socially and every social phenomenon is a sense of the production process. Meurer (2005) highlights the CDA as an important tool for awareness of people about how language serves the ideological formations in maintaining power.

After the elections, Facebook (2014) released the figures related to the interactions generated. There was in Brazil within three months of the election campaign, 674,400,000 interactions. Of this total, 53.8\% of posts referred to the Rousseff, and $46.2 \%$ to Aetius. Dilma was mentioned more often in the North and Northeast; Aécio in the Southern States, Southeast and Midwest.

Facebook did volume assessment, but not the content. This study aims to investigate, based on Fairclough (2001), as each candidate was represented discursively over that period, what kinds of beliefs were produced and, consequently, that representation of reality social network offered.

The cybersociety which converges hypertext and cyberculture, sign up in the digital space, cyberspace which, according to Diniz (2008), became a construction similar to what is meant by a modern city focused on technology, cybercity in which the new language is installed. Lemos (2003) speaks of symbiotic relationship between society, culture and new technologies.

This study performs the template Fairclough (2001) proposed in Tilio (2010), incorporating precious recommendations Meurer (2005). The model is the definition of the following social problem: 'Why was the emergence of hate speech ever seen on social network? ', with the backdrop of hatred as a social problem factor in Brazil.

Fairclough (2001) proposes that social and discursive practices are analyzed not only by the use of the word, but also the image, from the perspective of semiotics, the science of all languages. Fairclough (2001) goes beyond the language issue considering that all language manifestations establish power games.

\section{Method}

This study used a combination of different theoretical and methodological approaches, aligning the Participant Observation and Critical Discourse Analysis (CDA). The first determines the place occupied by the researcher as an active member of the circle points, the second analyzes the text connections with social practices, especially in terms of ideology and hegemony (MEURER, 2005). Fairclough (2001, p.91) understands discourse as social practice.

After the first round of elections the social network began to be observed from 10 to 12 hours a day at random in three shifts, morning, afternoon and evening. The population's access to the internet reached 105.1 million people in the second quarter of 2013 (IBOPE, 2015). 77\% of them use social networks (SILVEIRA, 2014). In April 2015, the number of Brazilians on Facebook reached 92 million people (TARANTIS, 2015).

Intensive monitoring of Facebook has occurred in the sphere of 616 Internet users belonging to the time the researcher's relations circle, from its location, the state of Santa Catarina. Colonized mainly by Europeans (german, italian and portuguese people specially) from the second half of the nineteenth century, Santa Catarina is in southern Brazil and gave the candidate Aécio Neves (PSDB) the best electoral performance of the country (64.59\% of the votes).

Research participants have the following profile: men and women equally, in the range of 18 years to 65 years with high school or more, predominantly middle class (MATTAR, 2005). ${ }^{1}$

The work consisted in performing printscreen screens of Facebook, seeking to preserve the originality of speech, since they have dates and times of the collections. They selected 281 screens, arranged in software Excel spreadsheet using the following concepts (in a vertical column on the left.) in the following order $^{2}$ :

Aécio Neves, Dilma Rousseff, FHC (Fernando Henrique Cardoso), Lula (Luiz Inácio Lula da Silva), PSDB (Brazilian Social Democracy Party), PT (Workers Party) voters Pro-Aécio, voters Pro-Dilma, Robots and Media.These concepts were crossed with categories (horizontal line): Hate (at different stages), tolerance and convergence, bringing out modalities.

A final column entitled Other closes the table (right) and is a minimum of printscreens residual component that did not fit in the investigated concepts, such as the opinion of undecided, Internet users who had not declared voting and data on research, mode 'meta-search', whose studies deserve developments.

The arrangements were indexed hyperlinks, creating then a 'matrix sheet', a kind of matrix in which the terms can easily be displaced depending on the intended focus of study.

\footnotetext{
${ }^{1}$ The names and profile pictures were blurred with Adobe Photoshop CS6 software to preserve the anonymity of participants

${ }^{2}$ Alphabetical order of names 
The different stages of the impact of hate speech as proposed by Cortese (2015) imply categorize hatred that incites violence (E4); the more hatred (E3); and prejudice (E2). The stage 1 (E1) was not considered because it is unintentional manifestation of hatred, as the lack of a word or phrase might offend in a particular context.

Parallel to this, there was Systematic Literature Review (SLR) at the larger bases of interdisciplinary data, which is similar to the highly interdisciplinary aspect proposed by the CDA as pointed Tilio (2013). The review was based on the issue of hate speech associated with cybersociety.

Three databases with articles were used, Scielo, main portal in Latin America; Scopus regarded as the world's largest and the Web of Knowledge, recognized with the most demanding database in qualifying publications. The termscyber society and hate speech were used as keywords to search for items in these platforms.

A search with those keywords combined, however, did not produce any result, then settled by criteria do it with keywords hate speech and cybercities along the platforms to the terms without combination. In these parameters were found 807 articles, distributed as follows: 50.4\% coming from Scopus, $48.7 \%$ of Web of Knowledge, and $0.9 \%$ of articles coming from Scielo platform.

The keywords have the following result: hate speech 743 articles and cybercities 64 articles. These articles passed by constrictions so that the most relevant papers on the topic researched were identified.

Constrictions were sorting by relevance in the first instance, limiting the number of citations per paper in the second reading the titles and finally reading the summaries. In the case of Scielo platform of 9 articles found, four were selected by reading the titles. Of these, read summaries, 2 were included to complete reading.

In the case of the Scopus Cybercities keyword 30 brought results, and of these only those items with one or more quote was included, resulting in 11 articles. The titles of these articles were read and deleted by 9 do not fit in the context of research. The remaining two have their read summaries and were not included because they do not fit the context.

With hate speech, Scopus brought to 375 articles, which after ordering by relevance the first 30 were extracted. Only 6 articles had more than one quote and were available in full. The reading included all 6 items and reading the abstracts resulted in the extraction of a relevant article.

The Cybercities keyword in Web of Knowledge recovered 33 articles, 7 of them with one or more citations. In reading the sections 2 more articles were excluded, and the reading of the summary resulted in 1 Article extracted. The hate speech keyword recovered 375 items, and ordered by relevance had the first 30 analyzed. Nineteen had one or more citations and were taken to reading the titles.

However, only four were fully available. These had their read titles and abstracts, and extracted 2 articles in this search. The last constriction reading the summary, allowed to reach up to six most relevant articles on the topic searched among the 807 articles taken. Figure 1 provides the results of bibliometrics, demonstrating the merits of each keyword per database searched.

\section{Figure 1: Bibliometrics results by keyword and origin}

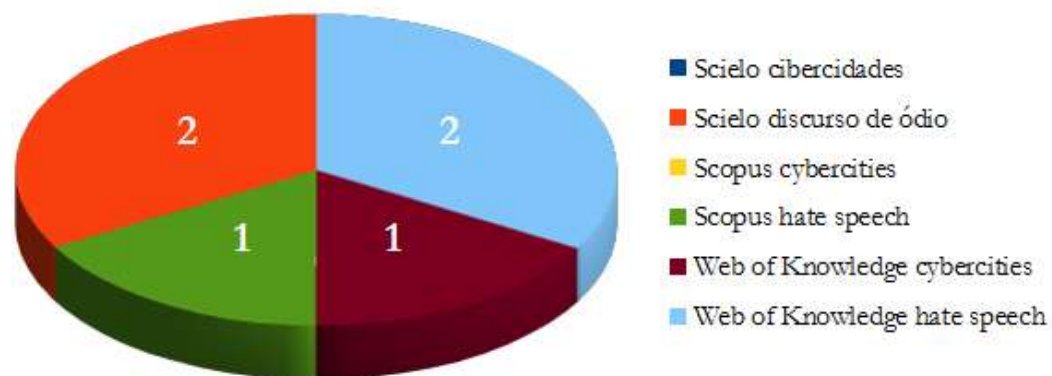

Source: QUEVEDO, 2015

No article was excerpted in searches Cybercities Scopus and Scielo for this reason are mentioned in the legend, but not marked on the chart. Scopus platform was that brought more articles at the beginning of bibliometrics, but the extraction, Web of Knowledge has shown greater consistency and presented more articles to read. Also it is realized that the term hate speech / hate speech showed higher amounts of articles, both in the initial search as the final results of the research. After Systematic Review of Literature and construction spreadsheet proceeded to the method. A Critical Discourse Analysis (CDA) included structural analysis, social and discursive practices, and the context in which the social problem identified from the point of view of the numerous languages available on the web. 


\section{Results}

Results from 281 screens captured through printscreen determined that hate between Brazilian people is concrete and cybersociety borders on incitement to terror and violence. Well away from the symbolic image of peaceful and friendly Brazilian conceived from the 1930s, especially with the works of Gilberto Freyreand Sergio Buarque de Holanda (REZENDE, 2015). Unlike in cybersociety, the Brazilian explained his bloodiest side.

Expressions of hatred the emerged relentlessly, regardless of possible punishment, as Internet users, who were not anonymous - had name, photo, released address - not to fear any criminalization.

In this part of the analysis proposed by Fairclough (2001) this is to look at the reality created by speech, since the texts are ideologically invested content and reflect power struggles in society. "Ideologies establish a foundation on which to support the ways of being and acting in the world" (MEURER, 2005, p. 102).

According to Meurer (2005), ideology is seen in the CDA as a way of conceiving the reality that contributes to benefit certain groups in detriment of others. Their analysis allows contextualize what kind of knowledge and beliefs are produced and, therefore, that the representation of reality the text offers (MEURER, 2005), since texts reveal identities and ways of thinking about the world (FAIRCLOUGH, 2001). In other words, the texts here reveal how they think the voters of Aécio and Dilma.

The representation of reality studied as discursive social practice and structural analysis (beliefs, ideas, texts) shows that Internet voters aligned to Aécio Neves candidate (re) produced the following beliefs:

a) Fear of communism

b) The possibility of fraud and conspiracy

c) Hate the opposing political party

d) Use of offensive words of profanity

e) Sexual Connotations: use the image of women, violence, rape, whoring, pedophilia

f) Social Segregation with stereotype of the 'good people'

g) Speech against corruption

h) Tolerance supported the naturalization of dispute between classes

i) Protection of values and the neoliberal economic policy model

Pro-Dilma voters (re) produced the following beliefs:

a) Condemnation drug use (alcohol and cocaine)

b) Use guerrilla to gain power

c) Allegations of physical abuse, verbal and psychological suffered

d) Prejudice Report

e) Speech against corruption

f) Tolerance supported in humor, praise, empowerment

g) Defense values contrary to neoliberalism

\subsection{Social and discursive practices}

The model Cortese (2015) proposes a flow between the less hatred and more severe in stages ranging from 1 to 4 , with its peculiarities. According to Cortese (2015), there is hatred when observed four basic criteria, in which hatred is caused by intentional discrimination against minorities: the intention (to offend), extreme and outrageous behavior, the 'act' to cause the action and distress severe emotional.

In Stage 1 (E1) the speech offends, but not for this purpose. For example, a deaf person literate by the Língua Brasileira de Sinais (Libras) $)^{3}$ does not accept being called 'disabled person', although this is the politically correct term used in Brazil. But a listener who is unaware of this reality can easily call it even "disabled". ${ }^{4}$

\section{${ }^{3}$ Brazilian Sign Language}

${ }^{4}$ Deaf from birth, or pre-linguistic, does not accept being called disabled person because of the principle that may not have disabilities what he never had. Deaf is inserted into the deaf culture, and carrying deaf. It is different from the person who lost his hearing with age or other reason, the post-linguistic, having acquired or developed the language, the person with hearing loss, the adept oralism and Portuguese. This difference determines even deep ideological divide between these groups (QUEVEDO, 2013). 
In Stage 2 identifies offenses by prejudice. Already Stages 3 (S3) and 4 (E4) are considered more impactful because there is incitement to hatred and terror, respectively. Latin, incitare is a verb with subtle meanings in Portuguese: can represent encourage, lead someone to do something; but also trigger or have a reaction: a provocation, one enraivecimento. In the E4 it is a quality hatred: what hurts with intent to cause fear and terror to the social environment. As in any action that involves cognition language and language, it exposes what is thought by word and its semiosis multiple texts. The analysis of social and discursive practices motivate the time the researcher asks "Who writes texts for whom? Why? Under what circumstances? (MEURER, 2005). Here begins the inserted semiotic analysis in social and discursive practices arising the intersection of the concepts chosen to compose the matrix with the categories determined in advance.

\subsubsection{Aécio X Dilma: a matter of slanders}

The discursive representation of the candidate Aécio Neves and Dilma Rousseff, the interpretation of voters, is a collection of slanders, offenses located more on the level of injury which, under Brazilian law, is a crime against honor: badmouth someone's reputation. The discursive clipping (shown in the Excel spreadsheet), Aécio Neves (Table 1) appears, in the view of opponents voters, as playboy, cocaine user, drunk, liar and wife beater (Stages 3 and 2 violence).

Table 1: Conceptions attributed to Aécio Neves candidate

\begin{tabular}{|c|c|c|c|c|c|c|}
\hline 4 & A. & 8 & c & D & E & $F$ \\
\hline 1 & \multirow[t]{2}{*}{ CONCEPT } & & & & & \\
\hline 2 & & E4 (Violence incitation) & E (vincitement to hatred) & E2 (preconception) & Tolerante & Convergence \\
\hline 3 & & & & & & \\
\hline 4 & \multirow{10}{*}{ Aécio Neves } & & Cocaine 1 & Playboy & Savior & \\
\hline 5 & & & User (Cocaine 2) & & Search Aécio I victary & \\
\hline 6 & & & User (Cocaine 3) & & Warriot & \\
\hline 7 & & & Ler 1 & & Family man & \\
\hline 8 & & & Lier 2 & & & \\
\hline 9 & & & Wife beater 1 & & & \\
\hline 10. & & & Wife beater 2 & & & \\
\hline 11 & & & Drank & & & \\
\hline 12 & & & & & & \\
\hline 13 & & & & & & \\
\hline
\end{tabular}

Figure 2 shows how to partisan voters Rousseff, Aécio is linked to cocaine, being presented as a 'playboy' that leads to life partying with beautiful women. The (a) voter (a) Dilma quips: "User?" Aécio looks at the camera front, smiling, has in his arms a young and tanned girl.

With the right hand holds Aécio a large cup, the left seems to involve the girl, who also faces the camera and smiles. He wears a hat and a brown shirt already stained. She wears a red lingerie or bikini. Behind the couple a man with shirt and black cap raising arms throwing himself back, as if he did not appear in the photo.

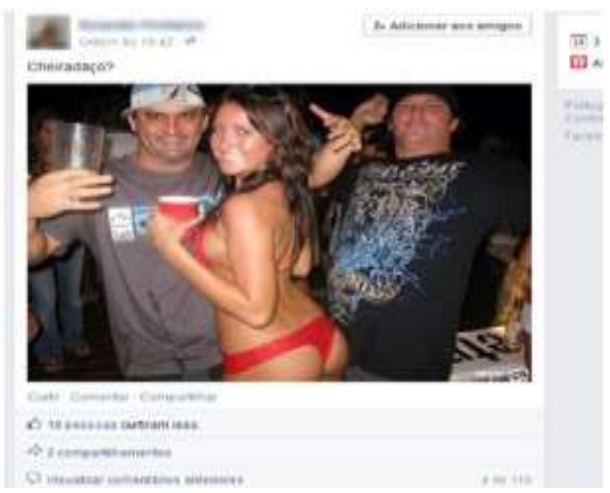

Figure 2: playboy life and wife beater

Finally, he is also accused of being a scout of women taking the campaign post with your name associated with death of Cristiane Aparecida Ferreira model, which, according to the mining police, carrying millionaires values in the service of the toucan monthly allowance scheme. Prejudice of Dilma supporters weighing on Aécio is it being a "playboy", "daddy's boy". In tolerance levels, the candidate is seen by their constituents as a "savior", the man who will save Brazil from being a communist dictatorship as a 'family man'. A true victorious warrior. Already the candidate Dilma Rousseff suffers more attacks (Table 2). It is attacked with slanders that encourage terror and fear, and incitement to hatred. There is a higher load of hatred of opponents voters who revile more (Stages 4, 3 and 2 on the hate scale). From the standpoint of Aécio voters, Dilma is a thief, stupid, thick, tapir, incompetent, bitch, ugly, false, untrue - a failure. 


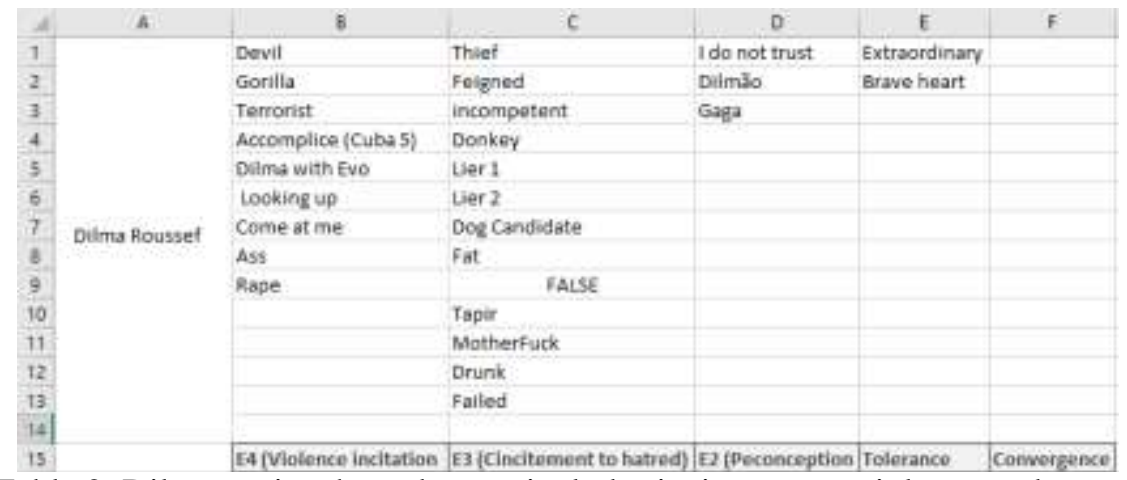

Table 2: Dilma against hatred range includes incitement to violence and terror

In Figure 3 Dilma appears with the image that is more associated by voters Aécio: the devil. Travesty of devil has horns gleaming red phosphorescent and pointed ears, wrinkles, vampire teeth and arched eyebrows. She is smiling malevolently, with a devilish look. A star on the forehead with the symbol of his party, the PT, closes the description of the image.

The author of the text (a) post reveals good Portuguese: words are pronounced correctly in cultured language, ideas have cohesion and consistency with the speech (a) netizen. It follows this post until that moment shared by 367 Internet users and confirmed by 16 people. The opinion of a (a) user internet is: "Perfect!".

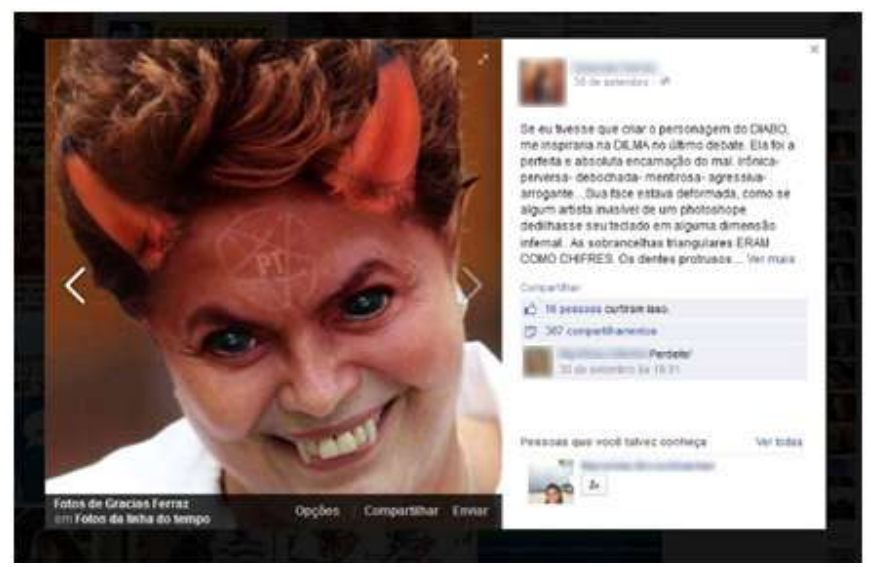

Figure 3: In the words of Internet users: the incarnation of evil

The message is a commentary about the last presidential confront on television between Dilma and Aécio.

If I had to create the DEVIL (sic), inspire me in DILMA (sic) in the last debate. She was perfect and absolute embodiment of evil, ironically, wicked, debauched, deceitful, aggressive, arrogant ... Herface was deformed, as if some invisible artist a photoshop in dedihasse your keyboard in some hellish dimension. The triangular eyebrows were like horns. The profuse teeth...

The author or post author has repertoire: know what is photoshop software and use expressions of cultured language, such as "protruding teeth", protruding forward. Aggression is free: Dilma "is ironic, wicked, debauched, deceitful, aggressive, arrogant": a true embodiment of evil. The words 'devil' and 'were like horns' are highlighted in uppercase letters. That is, Dilma is the 'devil' and his horns are the eyebrows of a woman.

\subsubsection{Voters Pro-Aécio X Voters Pro-Dilma: terror and hatred}

When leaving from the staff of each candidate orbit, the analysis of the confrontation between voters continues to reflect a hatred of overweight to others. Thus, it can be seen in comparing Tables 3 and 4 is a clear overlap between the two groups regarding the use of hate speech.

A speech hegemonically overlaps over another. Under the terms 'Electors Pro-Aécio' and 'Electors Pro-Dilma' appear pre-selected categories from the themes that predominate in the messages being repeated in gender and marked with ordinal numbers when the content of speech also repeats. 


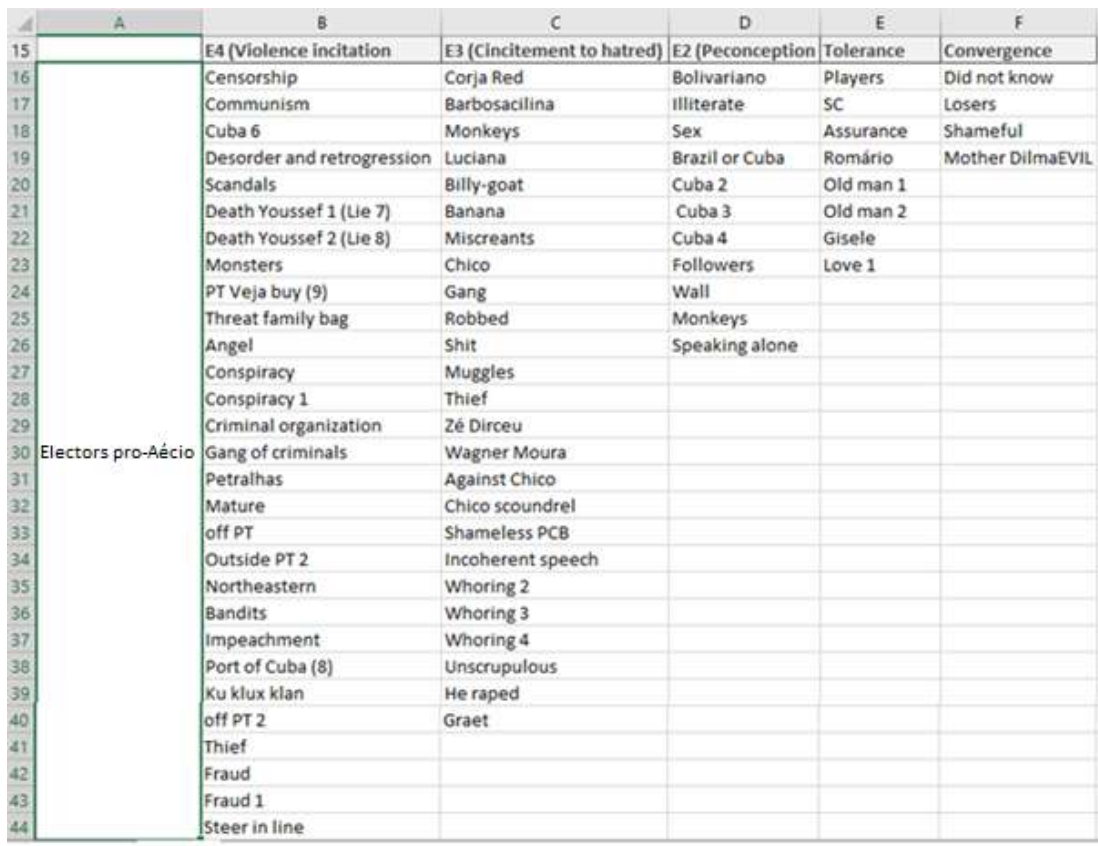

Table 3: categories identified under the concept 'Electors Pro-Aécio'

\begin{tabular}{|c|c|c|c|c|c|c|}
\hline 4 & A & $\mathrm{E}$ & c & D & E & F \\
\hline $4 \mathrm{a}$ & & & & & & \\
\hline 49 & & E4 (Violence incitation & E3 (Cincitement to hatred) & E2 (Peconseplion & Tolerance & Convergence \\
\hline 50 & \multirow{21}{*}{ Hectan fro-aim: } & Sulcide & Cleaning lady & Blonde & I love you & Did not know \\
\hline 51 & & Powder (Cocaine 4] & Dumb & Left and right is & Artists & Losers: \\
\hline 52 & & Guernila & Law Aurea & Left and right & Marina Lima & Shameful \\
\hline 32 & & Rejection Aécio & Right crazy & Racist and homo & Congratusations (SFM) & Fathes Aécio \\
\hline 54 & & Airplane's samba & Salary Adcio & Macimba & Ants & \\
\hline 55 & & Overdoses & Traffic & & Ellen Olêria & \\
\hline 56 & & Hate on the web & Corrupt & & Veja I & \\
\hline 57 & & Duvivier aggression & Privataria PSDA & & Veja 2 & \\
\hline 58 & & Wheelchair ageression & Jaguar & & Veja 3 & \\
\hline 59 & & Unfortunate & Dilma 45 & & Veja 4 & \\
\hline 60 & & Culture of hate & & & Veja 5 & \\
\hline $6 t$ & & & & & Jesus/IPI & \\
\hline 62 & & & & & Contest & \\
\hline 63 & & & & & Hope & \\
\hline 64 & & & & & Veja 6 & \\
\hline 05 & & & & & Militancy & \\
\hline 66 & & & & & Solange & \\
\hline 67 & & & & & Caleano & \\
\hline 68 & & & & & Carpet & \\
\hline 69 & & & & & We & \\
\hline 70 & & & & & zelia & \\
\hline
\end{tabular}

Table 4: Categories extracted under the concept 'Electors Pro-Dilma'

While hegemony is put clearly in numerical aspect, there is, of course, more expressions of hatred of one group to another, it is not considered here any variant of quantitative analysis. The qualitative analysis, however, is revealing.

It is noticed that the predominant hate speech to the Brazilian in the cut in question is what incites violence, fear and terror, more than cases of hate expressed or prejudice. Tables 4 and 5 show three stages with the greatest impact of hate speech. There is hatred of both parties, but one overweight in a group given the intentional quality of the choice of adjectives and nouns revealing his thoughts, which falls on the concept Electors Pro-Aécio (Table 3). In Stage 4 (E4) there is incitement to violence: netizens speak of conspiracy, fraud, declare their hatred of the opposing party, talk about disorder and retrogression on Rousseff's victory.

Are associated with the image of the Ku Klux Klan and the Catholic church, make clear his terror of communism and the proximity of Brazil to Cuba or Venezuela. Finally, since there begin to ask the impeachment of the elected president, a day after announcing the result of the election. It is also common to compare the figure of opponents with terror that arouses fear, as the use of stereotype or monsters of classic horror genre. Figure 4 shows the character of the American series Friday the 13th, Jason Voorhees, the murderer that promotes a massacre at a youth camp. 
In Jason image appears threatening with his white mask and a bloody sword in hand, in search of the opposing candidate. This is not only hateful, he thirsts for blood. Hate is such that travestied netizen character looking Dilma to kill her. Here you see someone who wants to kill with extreme hatred and terror refinements. ${ }^{5}$

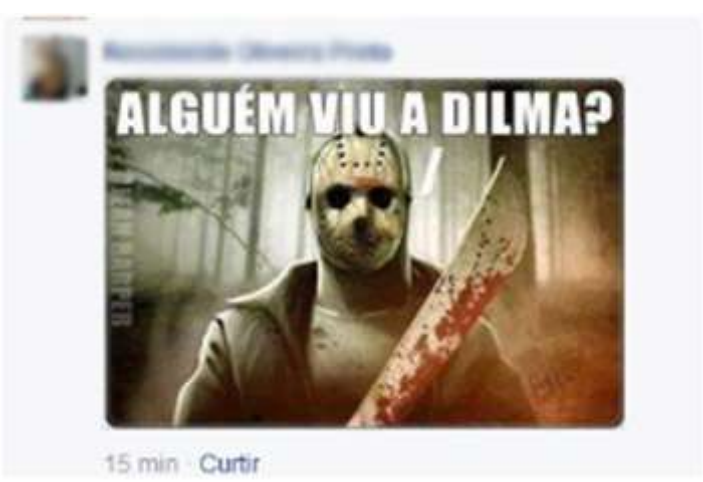

Figure 4: Incitement to violence with character who spreads terror and death

Cortese (2015) noted that although the stages delimited by it are four in number, there are intermediate stops that fit the observation. Thus, in the same corresponding stage (E4), indicating terror among Pro-Dilma voters, there is also blood, but differently. The terror that there is established is a terror that laments: according to the post, there was a wave of suicides among bank employees at the time of the opposing party government (Figure 5). Here you see a horror someone taking his own life:

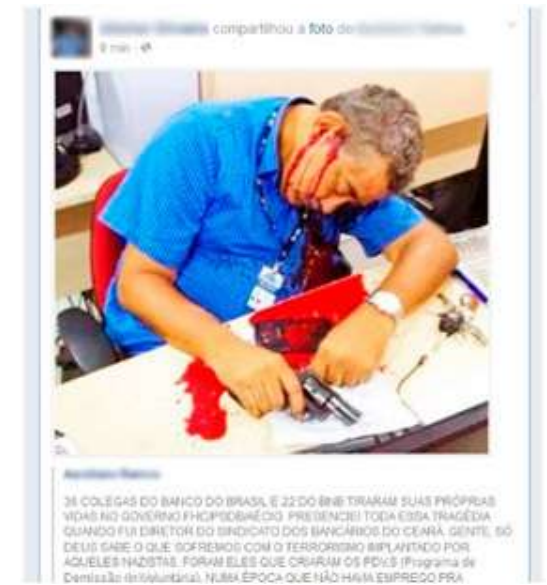

Figure 5: Suicides wave used as horror

The user says in the post:

36 colleagues from the Bank of Brazil and 22 of the BNB (BNB) took their own lives in government FHC / PSDB / Aécio. I witnessed all this tragedy when I was director of the union of Ceará bank. People, God only knows what we suffer from terrorism deployed by those Nazis were they who created the PDV's (Dismissal Program (in) Voluntary) at a time when there was no employment (...)

Dilma voters are also angry, but with other levels of aggression. In addition to the terror that is suicide, netizens post themes that infuse fear the conservative segments of the population. His main target is the fact that the opponent candidate would be cocaine user. However, half of the space devoted to terror, this case concerns an unusual practice: to be published, the posts spread and denounce terror practiced by the other group.

Terror is stimulated by speech attitude of the other, as the reports of these abuses, in which the facts become public in the virtual world, given the violence in the real world: a physical aggression to a wheelchair in São Paulo and other verbal , an actor in Rio de Janeiro, hatred of the Northeast.

That is, the Internet denounce terror practices exercised by voters who support his opponent, as shown in Figure 6, which reads: "Youssef money changer is found dead in hospital in Curitiba". The pro-Dilma voter claims that the opponents spread the rumor of the death of Youssef, author of complaints in plea bargaining to pay bribes to Petrobras directors, which would harm the candidate Dilma.

${ }^{5}$ Usersays in the post: "Has anyone seen Dilma?" 


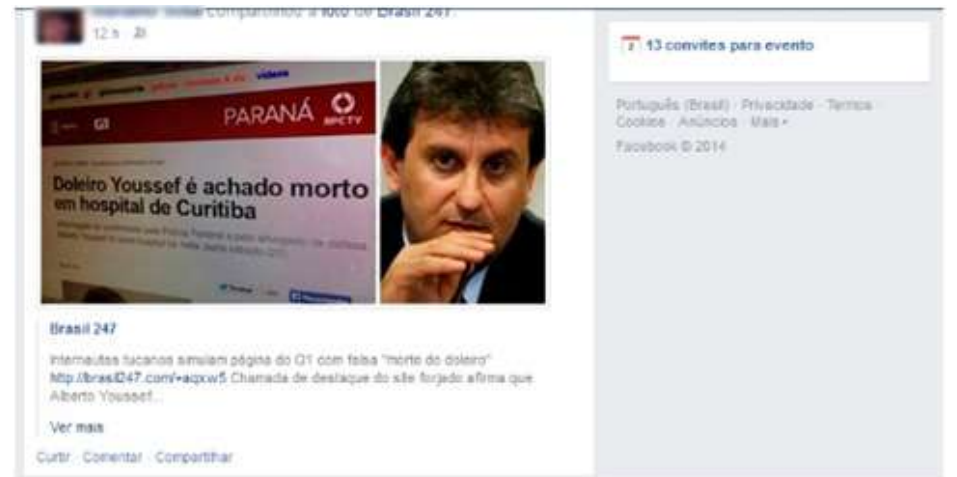

Figure 6: Announcement of the death of the author of complaints: it was a lie

Another striking demonstration of incitement to hatred is Figure 7, where the hatred of PT jumps in the category violence: the post, the voter of Aécio says: "Where is PT has pedophilia, prostitution, murder, corruption, lies. Let's end the PT before it ends with Brazil." The last sentence is a parody of the slogan "end the ants before it ends with Brazil", used in the 1960s by the Ministry of Agriculture for a national insect eradication campaign.

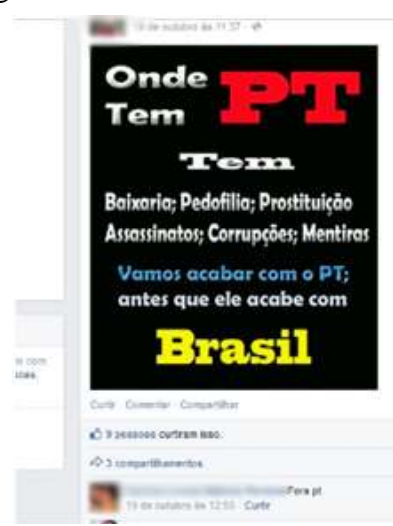

Figure 7: Speech that incites hatred of PT

Stage 3 of the pro-Dilma Electors portrays the same practice: there behavior complaint of voters linked to the opposing candidate, as shown in Figure 8, which reports the speech of a voter against Northeastern. The Northeast, which voted overwhelmingly in Dilma, became widespread hatred of target among voters of Aécio Neves.

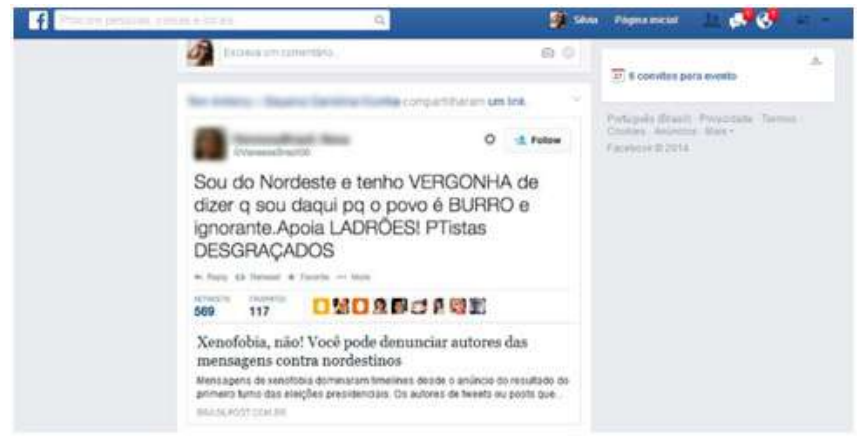

Figure 8: Group of Pro-Dilma voters reflects hatred behavior of Pro-Aécio voters

The post published by a pro-Dilma voter, which is a warning about xenophobia (dislike to what comes out), demonstrates this hatred: "I am the Northeast and I am ashamed to say I'm here, because the people are stupid and ignorant. Supports thieves! Petistas wretches. "Some words are in capital letters indicator on the Internet that the Internet user is crying.

\subsubsection{Mirroring}

Another observation is what might be called mirroring between the forces of the dispute. As in a battle, the exchange of fire was immediate, sometimes with the same weapons of the enemy. This mirroring took proportions at the level of behavior. What a group was, the other was also under the guidance of their beliefs and ideologies. 
Figures 13 and 14 reflect this relationship speculate. Figure 9 is an example: post day 10/17/2014, captured the 12:45, print images Dilma and Lula on the back of a truck, surrounded by donkeys, on backpacks and bags, like Northeastern migrants. PT flags flutter in the wind as a phrase in the truck warns: "Keep away."

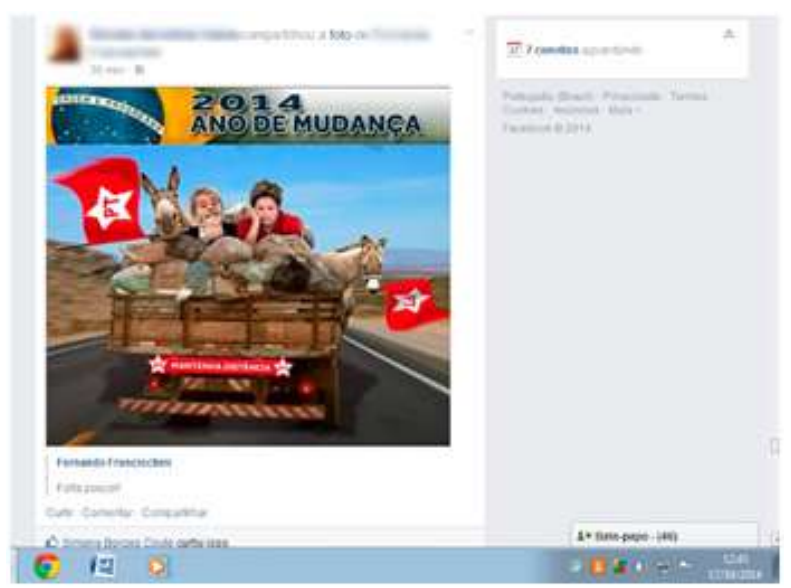

Figure 9: 10/17, 12:45: Voters Pro-Aécio launches fire

The reaction came following on 10/24/2014 at 17:55, and more weight: the same scenario, the body of the truck, appear beyond Aécio images of journalists working for the corporate media in Brazil, as the journalist William Bonner, anchor of the National Journal of Globo TV, the country's largest communication corporation. In the truck group, a heavier adjective: it is "garbage" then not only keep away, keep away from junk!, worthless things, contemptible objects (Figure 10).

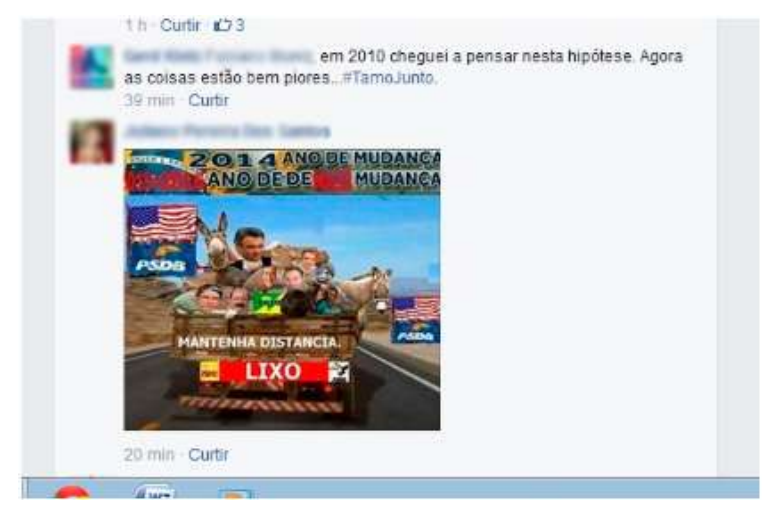

Figure 10: 10/24, 17:55, fire back

Mirroring the social network also gave to posting strategies: guidance that comments dishonest posts were "up" the trend up group and increase views determined the behavior not to comment on them for both sides. Here again, we have the mirror, as shown in Figures 11 (10/13/2014, 16h38min) and Figure 12 (10/22/2014, 12h12min).

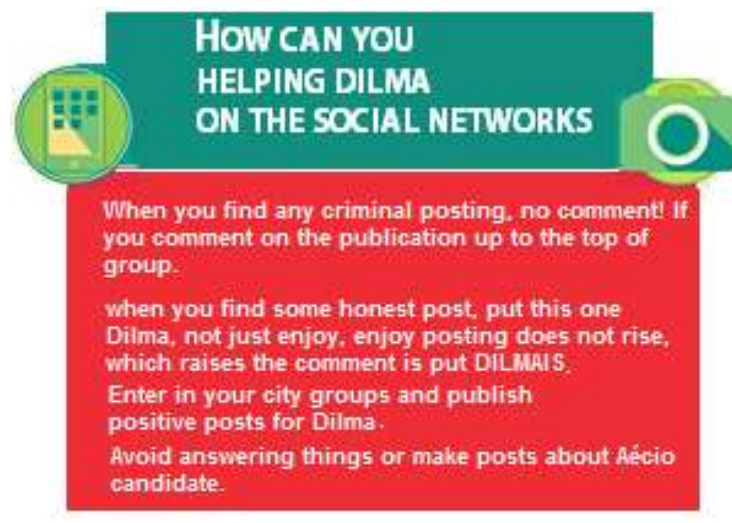

Figure 11: 10/13. 16:38: No comment warning 


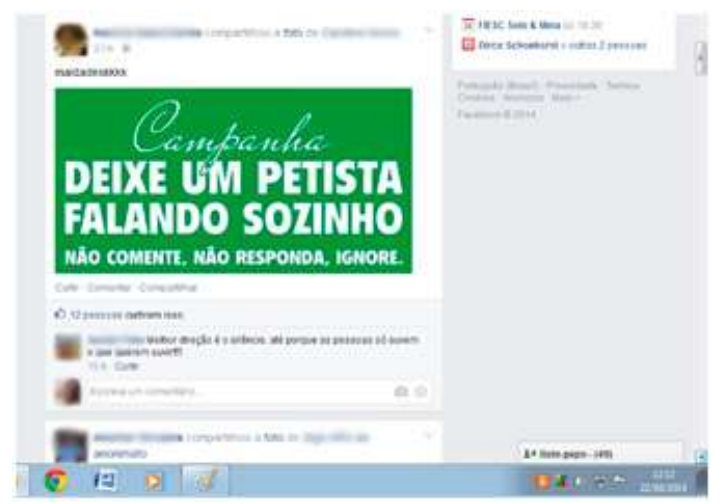

Figure 12: 10/22, 12:12: No comment - "ignore"

In the first, a text warns, among other details, "When you find any criminal posting not comment. If you comment on the publication rises to the top of the group." In the second, the guidance is similar. "Leave a PT talking to himself. No comment, no answer, ignore."

The mirroring behavior reproduced a maximum beliefs of the Brazilian people, both sides declared their faith in a religion African descent (Figures 13 and 14), exposing politically what one believes.
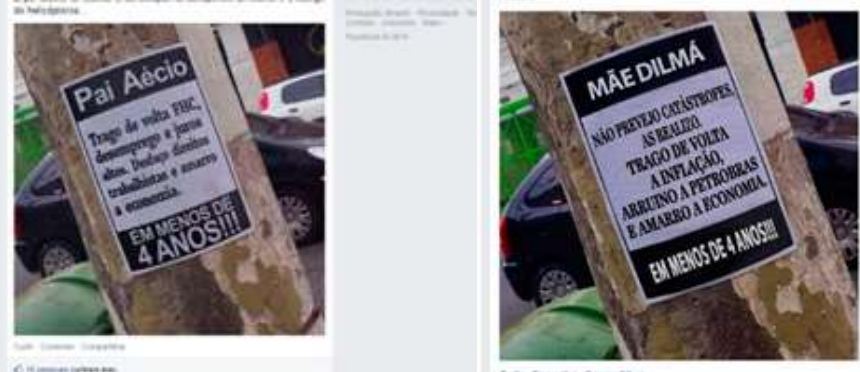

Figure 13: 10/18, 21:58: 'Father'Aécio and Figure 14: 10/20, 19:4: 'Mother' Dilma

Again the images appear in the same scenario, in this case, urban. The post with the ad has the right white car and left a black. In Figure 13 (10/18/2014, 21:58), the text proclaims: "Father Aécio - bring back FHC, unemployment and high interest rates SCRAP labor rights and tie the economy in less than 4 years !!!.." ".

The reaction was swift: two days after the same composition as shown in Figure 14, of 10/20/2014, 19:41, and reports: "Mother Dilma (sic) - I do not anticipate disasters, realize I bring back inflation Ruin (sic) a Petrobras and tie the economy. in less than 4 years !!! ".

\subsection{Social Barriers}

Here the model Fairclough proposes to evaluate the interests of social order involving the issue. There is interest (or interests) of social, public, to solve the problem, or, as suggested Tilio (2013) so that the problem is not solved? Therefore, it is necessary to understand the historical context of the critical point of view.

In 1995, while writing The brazilian people to the shores of the Sea of Marica, city of the south coast of Rio de Janeiro, the anthropologist Darcy Ribeiro (1922-1997) looked disbelieving changing possibilities due to the actions of politicians and government institutions (at the time Fernando Henrique Cardoso) ${ }^{6}$ who defended the model of liberal democracy seated in the precept of the property.

There is no evidence, however, that it [change] is reached. The Brazilian social order based on the implicit right to have and maintain unproductive property is so fervently advocated by the political class and the institutions of government that it becomes impractical. It is likely that the Rural Democratic Union, which represents landowners in Congress, is the most powerful organ of Parliament. It is unthinkable to make her admit the principle that no one can keep unproductive land under property rights in order to return the underused land to the Union for settlement programs (RIBEIRO, 2014, p.185).

6 Fernando Henrique Cardoso (PSDB) was the 34th President of the Republic, having governed Brazil for two terms (1995-2002), after releasing and become the main driver of the Real Plan in 1994, as the minister of the Itamar Franco government. 
Indeed, the composition of the National Congress after the 2014 elections leaves no doubt about the hegemony of the forces. According to a survey of Inter-Union Department of Parliamentary Advisory (Diap/acronym Portuguese), the Congress elected in 2014 is the most conservative since the return to democracy in 30 years.

Join an increase in the number of parliamentarians linked to conservative segments of society, including the military, police, religious and large farmers (MARTINS, 2014).

Figure 15 shows Diap prepared by the new composition of the National Congress with the 2014 elections and confirms what Darcy Ribeiro already provided in writing The Brazilian people: the ruralists continue their hegemony.

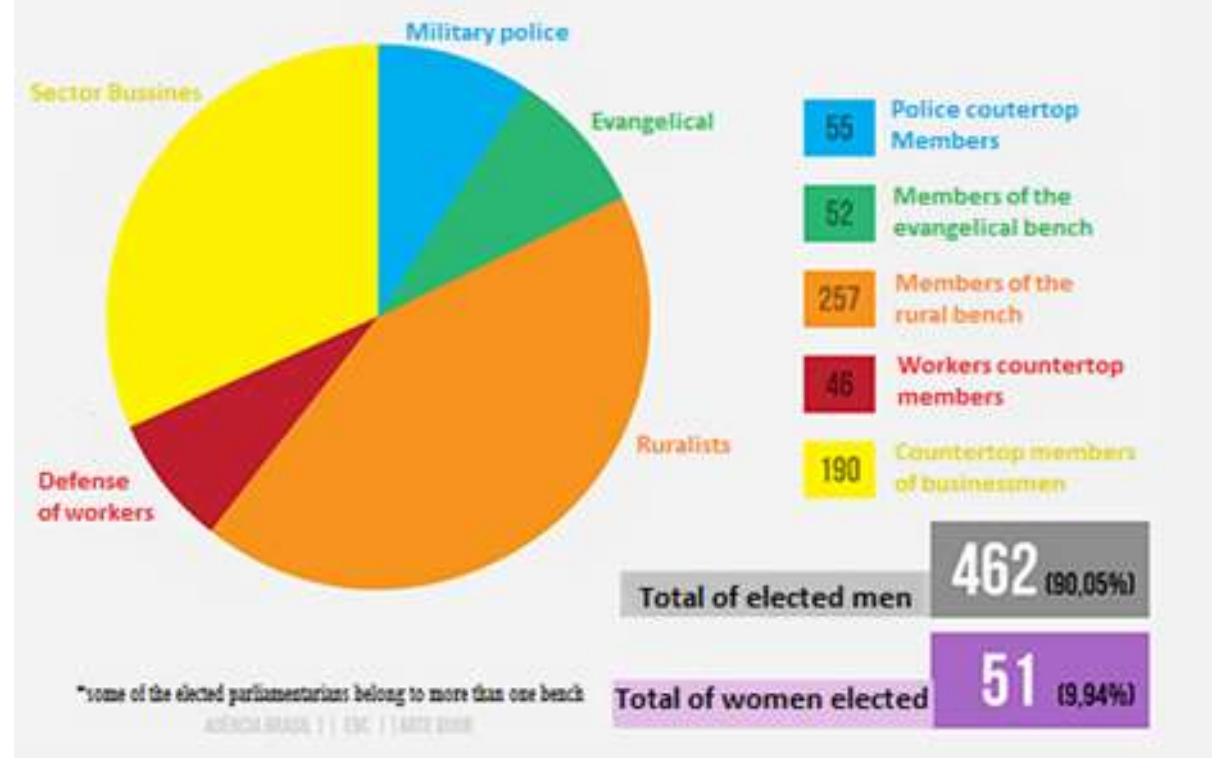

Figure 15: New composition of the National Congress keeps secular hegemony in Brazil Source: Diap, 2014 - Agency Brazil

The large farmers have now the largest party in Congress, with 257 elected parliamentarians. The second largest party representing the business interests (190 elected), followed by police Countertop members ( 55 elected), the evangelical bench (52 elected) and workers bench (46 elected).

\subsubsection{Context of the means social}

The emergence of hate speech in Brazil is not an isolated incident. There, in the world, a deep sense of hatred. Brazil won its spots in June 2013, with demonstrations, particularly of young people who took to the streets and were regimented by social networks. The protests began by price increases in the numbers of bus tickets and eventually culminating in the role of so-called "black blocks", masked groups left for destruction attacks as an expression of tactics and confrontation with the police.

A year later, in 2014, and with social movements in reflux, behold, a new campaign for the presidency in Brazil favors the emergence of more strife, in a direct confrontation between the candidates opponents in the second round of elections in October. Of course, new effervescence was made explicit in clashes among Brazilians.

This time, however, with differences: the demonstrations were composed by voters of all ages (and no longer captained by young people); for the first time had jumped the real-time web covers for making individual position on social networks, Facebook in unattained proportions. This is when emerging hate speech. But the aftermath is not alone, mixed up with the social and historical circumstances of the formation of the Brazilian people. Anthropologist Darcy Ribeiro begins by establishing settlements difference justifying the basis of the appearance of the Americas, North and South: for more than 500 years, with the discovery of the "New World" in contrast to the European discoverers of "Old World", two colonization styles to have established in their colonies (RIBEIRO, 2014).

The colonization of the north by "Nordic peoples" living conditions led itself to hand over the work that came to the colony. For these settlers, "the Indian was a detail, dirtying that landscape, to Europeanize, was to be rid of them. What were live where they wanted, free to be different, but far away, if possible, to another overseas, into the Pacific.

According to Ribeiro (2014), Brazil is built like a European colonial deployment based on technological innovations offered by the white and the most advanced forms of social order and ideological instruments of control and expression. 
There was a slow diffusion of the Portuguese language in a social entanglement of religion and power, controls embodied in a diffuser center of beliefs and values, formed by those who held the learned knowledge.

This determines the absence of a native ruling class (RIBEIRO, 2014). The miscegenation between Lusitanian, Indians and African slaves gave rise to the matrix people of Brazil. A people who work for the debate started in the 1930s with Gilberto Freyre and Sergio Buarque de Holanda won friendly and tolerant fame, showing, however, a deep, violent and aggressive hatred of the slave rebellion.

Built on the exploitation of cheap hand and servile work, the history of Brazil is riddled with bloody conflicts. Interethnic conflicts (RIBEIRO, 2014, p 153), in which "the Indians can not give what is expected of them," he provoked a war of extermination; while conflicts racial clashes, in which the three arrays were debated, found their bloodiest character in 400 years of slavery.

It is classist character a third type of conflict mapped by Darcy Ribeiro (2014) involving Brazilian populations. "Here they face, on the one hand, the privileged landowners, production of goods, which are predominantly white, and on the other hand, the working masses, these largely mestizo or black" (RIBEIRO, 2014, p. 158).

Associated with this context of business summits, as signals Ribeiro (2014, p. 162) there was the "bureaucratic patrician." "Every colonial life was led and governed, in fact, the civil bureaucracy of government officials and slave drivers and the (bureaucracy) military defense and prosecution bodies" (...) forming "a corporate-bureaucraticecclesiastical ruling class."

Ribeiro (2014, p.191) conceived the Brazilian social stratification in the figure of an imaginary rhombus (Figure 16), which puts the summit the "patronage of entrepreneurs, whose power comes from economic exploitation and wealth, and the patricians, whose command follows the performance positions as general, the deputy, the bishop, the union leader and others. "

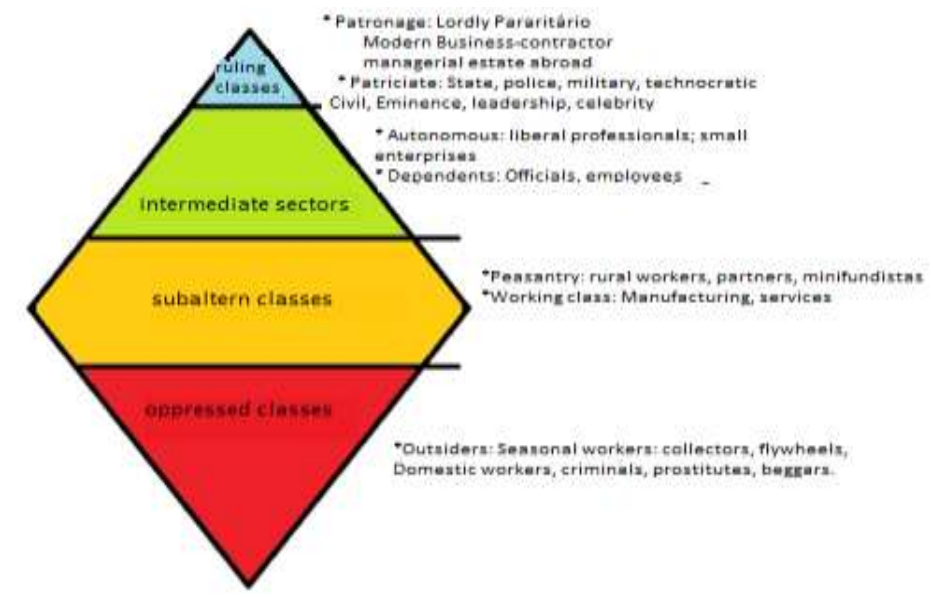

Figure 16: The Brazilian social stratification in the Darcy Ribeiro vision

In recent decades, it expanded to "managerial estate of foreign companies, which has become the dominant sector of the ruling class. It is the sector that employs the most competent technocrats and controls the media, shaping public opinion. It elects parliament and rulers "(RIBEIRO, 2014, p.191). Ribeiro Pyramid (2014) establishes a clear hierarchy: Below the dome appear the intermediate classes, made of professionals, police officers, teachers, lower clergy and the like. They all likely to pay homage to the ruling classes, seeking to take that advantage. (...). Here are the subaltern classes, formed by a "labor aristocracy" with stable jobs and skilled workers, and other pocket formed by small owners, tenants, large landowners managers. Below these pockets, forming the broadest line of lozenge of Brazilian social classes, it is the great mass of the oppressed classes, the marginal called, mainly blacks and mulattos, slum dwellers and the outskirts of towns. This class structure includes and organizes all the people, operating with a self-perpetuating system of social order. Her natural command are the ruling classes. Its most dynamic sectors are the intermediate classes. His most combative core subaltern classes and sarisan the oppressed classes (...) usually resigned to his fate, despite the misery in which they live, and their inability to organize themselves and confront the power of the owners. (RIBEIRO, 2014, p. 192).

In Brazil, emphasizes Ribeiro (2014, p.194), "the rich and poor classes are separated from each other by social and cultural distances almost as great as those that mediate among different peoples." 
The racial question is other barrier. The racial domination for centuries in Brazil continues to play its inequalities machine: the latest census conducted in the country in 2010, has detected what was already known or could be expected: the lower classes are still of mixed race $(43,1 \%)$ and blacks $(7.6 \%$ of the population), which form the majority (50.7\%) of the 190 million Brazilians (IBGE, 2010), followed by $47.7 \%$ white declared, plus 9 million and yellow 817000 Indians (LAMARCA, VETTORE, 2015).

The largest income differentials between white / black and white / brown are in cities with over 500,000 inhabitants (LAMARCA, VETTORE, 2015).The 2010 Census also highlights the persistence of differences in the distribution of racial groups, with a higher concentration of blacks and mulattos in the North and Northeast, and whites in the South and Southeast, which follows historical patterns of land occupation and perpetuation in social inequalities (LAMARCA, VETTORE, 2015).

The racial question still arises as an obstacle, starting, again, by the election campaign of 2014. For the first time the candidates were required to declare their color to the Electoral and the result showed widespread presence of whites. "If the national map was painted according to the politicians who were elected in October, little would be left of the image of multiracial nation: every four elected three are presented as white voters." (SARDINHA, 2015)

Magazine survey Congress in Focus (2015), based on information provided by elected to the TSE, shows that of the 1,627 elected candidates, 1,229 declared themselves white (76\%), 342 brown, 51 black $^{7}, 3$ yellow and 2 Indians.

Of the 27 governors elected in 2014, 20 are white. No one said black or indigenous. In the current Brazilian National Congress of 100 seats, 80 are occupied by politicians who fi or as white.

Of the 540 elected Congress, 81 deputies and 5 senators are considered'mulattos'. 22 elected to the House declared themselves black. There are no blacks among the 27 elected senators. Currently, there are only two who thus say himself: Paulo Paim (PT-RS) and Magno Malta (PR-ES), both in the mid-term.

According to Sardinha (2015), "the polls logic repeats what is seen in large companies and government offices: the higher the position, the less chance of a black occupy it."

\subsubsection{The issue of gender}

Although inequality between winning a man and a woman has decreased, the national average women are still paid $30 \%$ less than men (MARTINS, 2014). With most of the 190 million Brazilians, women (51\%) are more educated and extend their employment level (IBGE, 2012), but the study in 2014 on the statistics showed that when added to the racial and regional aspects, the differences they are even greater.

Held on analysis of the IBGE 2010 Census, the study Gender Statistics - 2014 shows that inequality in color, region and gender remains high for women, an issue to be considered in the evaluation of the interests of social order does not solve the problem.

The black and northeastern woman has the lowest average income of the country. The population of workers in the informal sector without access to labor rights, is higher among women than men (MARTINS, 2014).

The fight for women's rights is international and historically recognized. In Brazil, the feminist movement identifies a "second wave" from 1975, set by the UN as International Women's Year, when emerged numerous journals and movements in block awareness.

The same happened in the next decade, 1980. According to Joana Maria Pedro (2015), the main agenda of this feminism, linked to feminist movements, was "Our bodies belong to us." They did not want to undergo youth and beauty standards, questioning "sex as a defining behaviors and heterosexuality as the norm" (PEDRO, 2015, p.3).

They demanded the decriminalization of abortion, denounced rape and domestic violence. "A 'second wave' led to the emergence of women's role in public spaces, with a political and cultural agenda that included individual rights and behaviors" (PEDRO, 2015, p. 4). Criticism of the president of the office dress Dilma, beige and all in income compared to the hood of a gas cylinder, is one of those old patterns. The researcher asks why the controversy has surfaced, but because Rousseff a woman, in an act of "pure machismo" (PEDRO, 2015, p. 1). "Customarily it is required elegance, beauty and youth of the nation of first ladies and women of the elite. A lot has changed for women since the second half of the twentieth century, thanks to the so-called" second wave "of feminism. But not all guidelines have been met "(PEDRO, 2015, p.1).

${ }^{7}$ Blacks and browns is the way the Brazilian Institute of Geography and Statistics (IBGE) designates two ethnic nuances of the Brazilian people. 
The issue of gender also in the new composition of the National Congress in 2014 looks very old: there are 462 elected men $(90.05 \%)$ against 51 women (9.94\%) (MARTINS, 2014). Reaching the agendas of feminist movements, as pointed out, is therefore a "missing" issue in the evaluation of the interests to the problem is not resolved.

\subsubsection{The media elite}

Another survey of this work presents the first overview of the results regarding the media's role in elections 2014. The study shows that the Brazilian media occupied more space in the highest degree of hatred in the range of Cortese (2015), Stage 4 (E4) which incites terror (Table 5).

Matrix worksheet prepared in Excel displays the modalities for the concept media, which led to the initial understanding to be the behavior of the Brazilian media a causative agent and obstacles to focused social problem - the emergence of hate speech.

According to Table 5, it is a festival of horrors accusations and insults. Posts reproduce covers and reports of mainstream press that foment hatred and psychological terror.

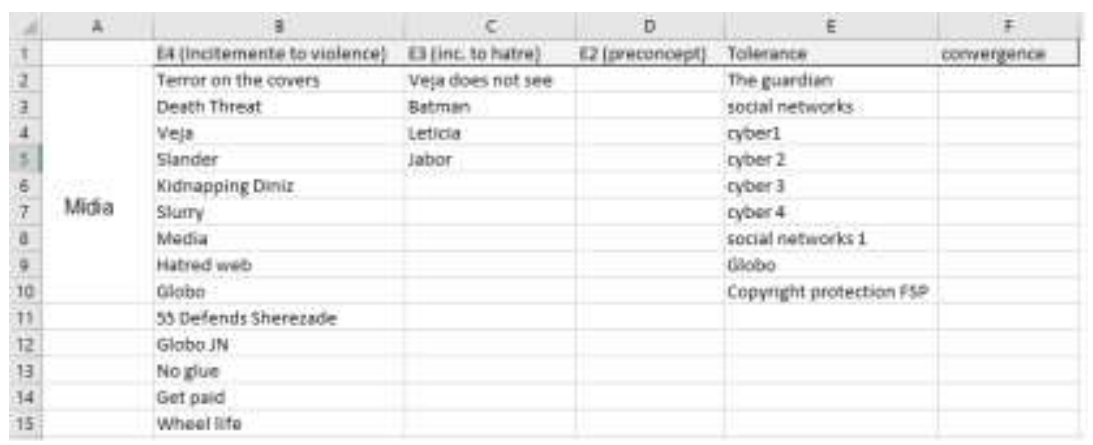

Table 5: Brazilian media reflected, but also urged, hatred and violence

One of the most frequent opponents to Rousseff's campaign is Veja magazine, condemned by the TSE to pay fine for spreading false information. There are also reports of attacks suffered by members or supporters of the PT.

On the eve of the election to the second round on 26 October, the newspaper O Globo (Death threat in Table 6) discloses that Aetius had asked the Federal Police to investigate death threats to him and his family on social networks. Another post reports that "with the election of Dilma more than 300 hate pages were created in Brazil." Note that it was "with Dilma's election" and not with the election campaign.

After the elections, the newspaper Folha de São Paulo published research demonstrating that more consistent contribution to the debate at the time would have arising from the traditional media. In fact, this study shows preliminarily that the media served weapon for both sides. And as it turns out, he found a way to distil their own poison. Not part of this study discuss the complex tangle of relationships involving the media activity in Brazil, whose valuable deepening is proposed for future work. It is, however, emphasize its strong concentration in the country.

The media power in Brazil is concentrated in the hands of a small group of families and companies, which dominate the system of production and dissemination of information and hold the vast majority of advertising resources (public and private) in the country (PALHARES, 2015). Among the larger groups, six families hold $70 \%$ of what is produced in information; the media concentration "is one of the major problems in Brazil and Latin America" (PALHARES, 2015). Rede Globo, owned by the Marinho family, is the largest media group in the country.

\subsection{Education and inclusion}

Strictly speaking, the Brazilian education has always lived in deficit. According to the researcher DermevalSaviani (2014) this problem comes in the origins of the country, with what you might call 'the first educational policy in Brazil', which was the regiment of King John III to guide the actions of the Governor General coming to Brazil, Tomé de Souza, who came the first Jesuits.

According Saviani (2014), the Jesuits came to the mandate of the king who determined the catechizing the Indians to expand the Christian faith, because John III was very Catholic and the Jesuits had ascendancy over him. The Crown maintained the Jesuits: sent resources for food and clothing, but not to create and build schools.

"We have a difficulty, a resistance of our elites to invest in education. It is already there, the origins, the shortage problem of educational development in our country (SAVIANI, 2014)." A little education available was aimed at elites. Education was for very few, destined for the clergy, the elite completing his studies at the University of Coimbra in Portugal. 
According Saviani (2014), the framework of the excluded: 50\% were women, $40 \%$ slaves, then the freed slaves, blacks, browns, destitute, orphans. "I left over tiny minority" (SAVIANI, 2014). We came to the empire with the same shortage. According to the researcher, the second government empire intended only $1 \%$ of its resources to education. In 1882 the government devotes $1.99 \%$ of its resources to education and $22 \%$ for the army. In the Republic, the Constitution of 1934 will determine the budget linking states and municipalities. With the states having to devote $20 \%$ of its resources and the Union 10\%, but that was never fulfilled (SAVIANI, 2014).

In the 1990s, when Darcy Ribeiro wrote The Brazilian people, gaps in education continued, especially in relation to higher education, which had not done investment. And why? "What we can say is that was already since before the Republic dissatisfaction of the conservative sectors with higher education, public and free" (SAVIANI, 2014).

This will come to be reflected in the Education Guidelines and Bases Law (LDB) ${ }^{8}$, established in 1996 in the government of Fernando Henrique Cardoso (PSDB), which are clearly defined the responsibilities of municipalities with primary education and early childhood education, and states and the high school. "But it is not there that higher education is responsibility of the Union, because in fact the Union was seeking to take the body out" (SAVIANI, 2014). The changes initiated by the Lula government were reflected in education, with public programs like Reuni, Prouni ${ }^{9}$, opening new campuses, new universities, investment in technical schools. "I have no doubt that the arrival of the PT to the federal government consisted of major political breakthrough" (SAVIANI, 2014). However, the historical deficit to be remedied continues pointing enormous needs, subject to be discussed in the next section, when changes are proposals forward in order to overcome the identified social obstacles.

\section{Proposals possibilities for changes to overcome obstacles}

Can hate be solved? What is the best strategy when the provocations arise? There would be a 'remedy' to hate? Many netizens were left with questions about these settings after October 2014. According to Cortese (2015), education is "the great intervention" to be held in the occurrence of hate speech.

Education stands as a major driving force of the possibility of change, particularly where hate speech falls into the question of prejudice, because no one is born prejudiced. "The prejudice is not innate, it is present interference of the socialization process, which requires the individual to change to adapt "(CROCHIK, 2015, p.19).

Prejudice is assimilated because it is learned culturally and socially, without necessarily a person realizing it. A child, for example, that it is biased in adulthood reflects acquired by social heritage, and may, with access to schools review their own thoughts. Objects, goods and ideas are already predesigned and when the child back to their interests they do not, or hardly ever, an autonomous reflection. Thus, the culture of transmission to younger generations, are already transmitted prejudices: ideas that should be assumed as their own without being able to think about their rationality and consequent membership or not to them (CROCHIK, 2015, p.19).

The awakening of consciousness allowed access to education is triggered with the use of language and language and "once someone becomes aware of the ideological value of the speech can resist it, and the ideological aspect may consequently lose or diminish their effect "(MEURER, 2005, p. 94). The understanding of the role of language as social practice can "cooperate for the advancement of the less privileged groups"(MEURER, 2005, p.94).

Thus, among the proposed changes possibilities to overcome the obstacles in the model Fairclough (TÍLIO, 2013) figure the large investment that is education at any level. Education is a great framework, which holds many variants. Access to and expanding use of technology, for example, is one of them, because the technology also involves a question of power.

In Brazil, the neuralgic point of education is located in the researcher Dermeval Saviani defines as "the drama of Procrastination" (SAVIANI, 2014). The 'tragedy of procrastination' is a whole series of postponements made with respect to investments in education, but are successively postponed, though no one steal to consider the urgency of education as a priority for the country.

This drama may have started with the history of Brazil, as we have seen, but comes up most markedly in the Republic, when the 1934 Constitution determines the budget linking States (20\%) and the EU (10\%), education, although "never met" in the words of Saviani (2014). Strictly speaking, there has never been sufficient investment to meet the demand of the Brazilian education.

\footnotetext{
${ }^{8} \mathrm{LDB}$ is acronym Portuguese

${ }^{9}$ Reuni - Support Programme for the Restructuring and Expansion of Federal Universities, Prouni - University for All Program 
Again the historical perspective needs to be rescued, identifying the postponements for investments, especially from the 1988 Constitution, in its transitional provisions established "in the next 10 years," so 1998 Union, states and municipalities should allocate at least $50 \%$ of its resources to a double objective: to universalize primary education and eradicate illiteracy. Saviani (2014) maps the steps:

Two years before that period in 1996, the program FUNDEF ${ }^{10}$ is hereby established, which pursued the same goal for more 10 years, designing the goal then to 2008. However in 2006 wins the FUNDEF and he is replaced by FUNDEB $^{11}$ in early 1997 , now within 14 years, is projecting there for 2020.

But that is not all. According to Saviani (2014), the "drama of procrastination" unfolds with repetition perspective for the future:

The LDB which was passed in 1997 establishing the decade of Education to start a year after publication comes out, then 1998 - 2008. In 2001 approved the National Plan of Education 10 years also to achieve this goal. He won in 2011 and this goal was not met. In 2007 the government launched the PDE (Education Development Plan) which provides that goal for 2022. I mean, are always stalling. I joke that this tuning fork probably in 2022 we will have another plan planning something for 2040 and so we reach the end of the 21 st century without resolving a problem that the major countries of the world decided in the late 19th century.

There are also issues surrounding. The universalization of basic education in Brazil, covering $98 \%$ of the children is to Saviani (2014) a "universal access", which established the so-called continued progression, ie the progression independent of results. But the problem is not only access, the problem is the conclusion. In fact, "it is only when universalized all children who enter the complete it" (SAVIANI, 2014).

According Saviani (2014), this "drama" in our country "will not be resolved until it is actually to take what is promised in the speech, that all preach that education is the first priority. Education is strategic for society of knowledge. Everyone says it, but not put into practice. "

Increase resources for education is a proposal to overcome the social obstacles to the hate speech problem, addressed in this study. Saviani (2014) believes that for the Plano Nacional da Educação (PNE) ${ }^{12}$ should incorporate two key positions: one is the financing, the other the question of teaching.

The researcher says that we must "increase significantly and immediately resources for education Doubling resources, spending 5\% of GDP to $10 \%$. Investment in Brazil has to be massive, just so it will demonstrate that education will have priority "(SAVIANI, 2014).

The issue of teaching, in turn, has two points to be attacked: training and the professional standards. Minimum wage and working hours $50 \%$ in class and 50\% outside it. "Without this, with flat wages ... the Magisterium has no social recognition, very low wages, are six years of study not socially valued. It is necessary to value the profession" (SAVIANI, 2014).

This study not socially valued away teachers learn in public schools of their own public, when it touches them to pursue the profession. According Saviani (2014):

Today most of the teachers who teach in public schools is formed in private schools of questionable quality. Teachers trained in public, and they are few, most will not go to public school. Or go to private, for the elites, or just going for a master's or doctorate. He will not teach in the public schools of basic education. So the public school is hostage to the low quality of higher level of training, the commodified schools.

The media also has a damaging fact in relation to education, according to the researcher to constantly emphasize that public education has no quality and have private. As Saviani (2014), private education has more quality than the public only in some schools that are the exception, which serve the elites and are unable to afford the high school. "The poor quality of public schools has a lot to do with the poor quality of private network that professionalize teachers at the college level."

There is no doubt that "economic inequality systematically undermines the democratic functioning" (PESCHANSKI, 2012, p. 27). The fact arises from two mechanisms constituted by the bias of social analysis: the rich have easier access to decision makers and the ability to influence them, including illegally (PESCHANSKI, 2012).

${ }^{10}$ FUNDEF - Fund for Maintenance and Development of Fundamental Education and Teacher Enhancement

${ }^{11}$ FUNDEB - Fund for Maintenance and Development of Basic Education and Education Professionals of Valuation

${ }^{12} \mathrm{PNE}$ - National Education Plan 
Thus, the bias politically favors those who control the flow of investments. According Peschanski (2012, p. 30), "If there is no investment, the labor market is weakened, damaging workers (fewer jobs) and burdening the state (less tax revenue and more transfers to social policies)".

The researcher Dermeval Saviani (2014) believes and argues that free the country of the "Drama of Procrastination" is a viable project. For him, it becomes simple:

Is it impossible, is it difficult? It's not difficult. It's simple. There are political obstacles stemming from this situation. This defeatist mentality positivist is in the minds of politicians ... It is not that difficult. It's the same with the resources. The economic issue is the economic model. In the 1930s, the car was the flagship of the economy. There were auto parts stores, and also the very construction, urbanization of cities, contractors who illicitly enriched themselves with the works. So changing the economic model, if you move the economic development axis of the country, expands education for the whole country, with highly paid teachers... What these teachers will make the salary? Move the economy, consumption, enable trade to meet this demand. We need to double the investment (in education) and move the axis (the economic model). Even in a capitalist framework, from the capitalist point of view, changing the axis streamlines up the economy in the same way, with the advantage that has no side effects.

According to the researcher, Brazil needs to walk for a change of economic model to transform education, developing a universal process of a school with better quality. "There must be a break with this order, which is necessary because that order has no more solution. Then, there are two exits. Either we break, socializing the means of production, or returned ago"(SAVIANI, 2014).

\section{Conclusion}

The hate speech experienced by Brazilians in the 2014 presidential elections was installed due to various peculiarities, as it turned out. No doubt the fiercest election in 30 years since the end of military dictatorship also determined the first confrontation in the social network most used by Brazilians. In the second round of these elections, between 5 and 27 October 2014, the two armies faced each other in the virtual world, making use of speech as weapon to defend in the cybersociety the respective candidates, each with a national project. Rattled off was a terrible hatred, the highest degree of impact, which is the incitement to violence, followed by smaller impact scales, such as the use of prejudice and discrimination.

The nuances, however, were very different, as demonstrated. Hate speech can consider offense against the honor characterized as a crime in Brazil. The attacks started from both sides, but the level of attacks against elected President Dilma Rousseff came in much higher pitch to the opponent candidate Aécio Neves.

This framework was based on two poignant aspects: first, the fact that it is a woman - the first elected president in a country whose agendas of feminist movements are yet to be conquered - and second, the investment of her government in public policy aimed at inclusion in a nation that historically is a 'inequalities machine'. Research has shown that the roots of hatred are founded on the following factors: dispossession from slavery colonization of the country, social stratification, chaotic urbanization, poor land distribution, conflicts of civil war, political persecution, corruption, media concentration, historical lack investments in education. The new slogan of the government "Brazil, Educator Motherland" beckons with possibilities of changes in a key area to progress happen. But he runs the risk of becoming innocuous if not come accompanied by massive resources, ending a systematic delays in investing in the area, observed since the colonial Brazil.

It must also return to teaching the social value of the profession that one day class already owned. Education has the potential to become the major driving force behind a new economic design to the country, able to exercise a break in the neoliberal model. Double investment in the area and move the national economic development axis are pointed questions as concrete possibilities of overcoming social obstacles involving the research problem: the emergence of hate. For social projects succeed and inclusion policies advance it is necessary to an upsurge of work aimed at reducing social inequalities. However, any government that really wants to make this project need to act in relation to the agrarian question, the interests of employers classes remain untouchable. Just as cannot ignore the media regulation of urgency, which showed interest in spreading terror in the period surveyed. It was found a behavior speculate among netizens, here called mirroring. Speeches and languages, including the point of view of the images, have been copied from side to side. One difference was that Internet users connected to the voters Pro-Dilma group receiving party lines, as a strategy, through the network, while Pro-Aécio group seemed adrift in the debate. This study showed that although the speech linked to incitement to hatred has been hegemonic, won the election speech less assaulted. The Brazilian, capable of deep-seated hatred that goes beyond the legal limits, often see violence on the other, not himself. It confirmed too that Brazilian can be friendly and peaceful but also deeply violent and threatening. Especially with those people in social and economic inequality. 
In the midst of so much hate, it is worth highlighting the role of tolerance, characteristic of those who know how to listen to their opposing views or that only supports diversity. Posts with advertisements linked to mood seemed to cause more emotional effect, positively surprising Internet users voter, much more than the criticism.

Reflect about the differences a gap of educated and peaceful coexistence is presented as an alternative to the hateful behavior. Nothing easy is faced with hate speech and resist with the other cheek. Not here said that this should be the rule. But given the impossibility of such transcendence, learn to diverge with respect may not be a bad idea. Probably even be the best way to create a peace camp anywhere where people live with different ideas. Different, yes, but respected.

\section{References}

BRASIL 247. Six families control 70\% of the press in Brazil. Available in http://www.brasil247.com/pt/247/mundo/92535/Seis-fam\%C3\%ADlias-controlam-70-da-imprensa-noBrasil.htm; access on April 2015.

BRASIL IBGE. Women are better educated than men.Available in: Noticias-censo?id=1\&idnoticia=2296\&t=censo2010-mulheres-sao-mais-instruidas-que-homens-ampliam-nivel-ocupacao\&view=noticia, accessonMarch 2015. Half of Brazilians have access to the internet in 2013. Available in http://www.brasil.gov.br/infraestrutura/2014/09/ibge-metade-dos-brasileiros-teve-acesso-a-internet-em-201, access on March 2015.

CORTESE, A.J.P. Cortese, A. J. P. (2006). Opposinghate speech.Westport, Conn: PraegerPublishers.Available in Library of CongressCataloging-in-Publications Data. Available in: http://www.worldcat.org/title/opposinghate-speech/oclc/60839350?page=citation, access on March 2015.

CROCHIK, J. L. et al .Relationshipsbetweenprejudice, ideologyandattitudestowards inclusive education Estud. psicol. (Campinas), Campinas, v. 26, n. 2, p. 123-132, June 2009.

Availablefrom<http://www.scielo.br/scielo.php?script=sci_arttext\&pid=S0103166X2009000200001\&lng=en\&nrm=iso >.access on March 2015.

DINIZ, L. A. G. .Cyberculture and literature: hypertext and new textual architectures. São José do Rio Preto: Alea Estudos Neolatinos, 2008.

FAIRCLOUGH, N. Speech and social change. Coord. trad.rev. technical and pref. I. Magalhães. Brasilia: Publisher University of Brasilia, 2001.

IBOPE. Number of people with Internet access in Brazil reaches 105 million. Available in: http://www.ibope.com/pt$\mathrm{br} /$ noticias/paginas/numero-de-pessoas-com-acesso-a-internet-no-brasil-chega-a-105-milhoes.aspx, access on March 2015.

LAMARCA, G .; VETTORE, M. New Brazilian racial composition according to the Census 2010. Available in: http://dssbr.org/site/2012/01/a-nova-composicao-racial-brasileira-segundo-o-censo-2010/, accessed on March 2015.

LEMOS, A. Cibercultura: some points to understand our time. In: Lemos, A; Cunha, P. (ed.). Glimpses of cyberculture. Porto Alegre: Sulina, 2003.

MARTINS, D. Income inequality falls, but women still earn 30\% less, says IBGE. Valor Economic newspaper, 10/31/2014. Available in http://www.valor.com.br/brasil/3760452/desigualdade-de-renda-cai-mas-mulherainda-ganha-30-menos-diz-ibge, access on March 2015.

MARTINS, H. More conservative elected Congress can limit advances in human rights. Available in http://agenciabrasil.ebc.com.br/politica/noticia/2014-10/mais-conservador-congresso-eleito-pode-limitaravancos-em-direitos-humanos, access on March 2015.

MATTAR, F.N. Marketing research: methodology and planning. Sixth Edition. São Paulo: Atlas, 2005.

MEURER, JL Text genres in the critical analysis of Fairclough.In: MEURER, JL et al (eds.). Gender theories, methods, debates. Sao Paulo: Parable Editorial, 2005.

PALHARES, J.E. Communication dilemmas in Brazil. Available in: http://cartamaior.com.br/?/Editoria/Politica/Osdilemas-da-comunicacao-no-Brasil\%0D\%0A/4/15378, access on March 2015.

PEDRO, J.M. My Body, My Rules. Journal of History of the National. Avaible in Libraryhttp://www.revistadehistoria.com.br/secao/capa/meu-corpo-minhas-regras, access on January 2015.

PESCHANSKI, J.A. The "squatters" and economic. Occupy inequality / protest movement that took to the streets. Sao Paulo: Editorial Boitempo 2012.

REZENDE, J. Democracy in Gilberto Freyre and Sergio Buarque de Holanda. Available in: http://www.revistas.usp.br/plural/article/view/68027/70597, access on May 2015. 
RIBEIRO, D. The Brazilian people: the formation and direction of Brazil. São Paulo: EditoraSchwarcz, 2014.

SARDINHA, E. Only $3 \%$ of those elected in 2014 is as black. Available in: http://congressoemfoco.uol.com.br/noticias/so-3-dos-eleitos-em-2014-se-declaram-negros/, access on March 2015.

SAVIANI, D. Dialogue without frontier: society, history and education in Brazil. RTV Unicamp, 2012. Available in https://www.youtube.com/watch?v=YgWUpP4xxRM, access on May 2014.

Interview with DemervalSaviani. Post held by: <Silvia Quevedo>. State University of Campinas (Unicamp), on May 2014.

SILVEIRA, S.A. Among the trolls, robots and activators: elections on the internet. Le Monde Diplomatique (Brazil), year 8, paragraph 86, September 2014.

TARANTIS. Growing Brazilian access on Facebook. Available in http://tarantis.com.br/brasileirosnofacebook/, access on April 2015.

TILIO, R.C. Revisiting Critical Discourse Analysis: a theoretical and methodological tools. Magazine e-subscripted: Journal Letters Course of UNIABEU, Vol 1, No. 2 (2010). Available in

http://www.uniabeu.edu.br/publica/index.php/RE/article/view/21., access on May 2013. 